\title{
THE LIMITS OF INTERPRETATION IN THE LAW OF CONTRACT
}

\author{
Andrew Robertson*
}

In the law of contract questions of risk allocation properly turn, where possible, on interpretation of the agreement. This article will explore the limits of that approach. It will do so by considering two doctrines that lie at the boundaries of contract interpretation: the implication of terms in fact and the remoteness principle. Both doctrines have been commonly understood as gap-filling rules, but in two influential judgments Lord Hoffmann sought to recast them as interpretative principles. It will be argued in this article that the implication of terms in fact can properly be regarded as an interpretative exercise, but the same cannot be said of the application of the remoteness doctrine. The implication of terms in fact can helpfully be understood as interpretative, provided care is taken to explain the paths of reasoning leading to the conclusion that a contractual instrument must be understood to include a particular unexpressed term. Because no common paths of interpretative reasoning can be identified for the determination of remoteness questions, it is unsettling and counterproductive to attempt to take an interpretative approach to these questions.

\section{INTRODUCTION}

Because the law of contract is primarily concerned with rights, obligations and allocations of risk that are created by contracting parties, its primary mode of problem solving is interpretative. Legal advisers and courts quite properly turn first to interpretation to resolve questions about which party bears a particular risk. While any problem-solving exercise must begin with interpretation, as one moves away from the direct application of clearly expressed terms the agreement necessarily becomes less and less determinate. A significant difficultly in the law of contract lies in determining when the interpretative process must end, and what principles should be applied to resolve questions that cannot be resolved through interpretation.

The implication of terms and the remoteness limitation on the recovery of contract damages provide ideal subject matter for considering the limits of interpretation in the law of contract because they lie at or around the point at which interpretation shades into gap filling. In recent years interpretation has come to be recognised as one of the most important topics - perhaps the most

* Professor of Law, University of Melbourne. 
important topic - in the law of contract. Lord Hoffmann has played a central role in the rise in the prominence of contractual interpretation, and in the modern development and explication of its principles. In the latter years of his great judicial career Lord Hoffmann sought to extend the reach of those principles, championing interpretative approaches to the implication of terms ${ }^{1}$ and remoteness of damage. ${ }^{2}$ Neither development was novel, but both have attracted a great deal of attention around the common law world.

Lord Hoffmann's interpretative reformulations of implication and remoteness have had mixed success. Both have generated controversy in the academic literature. ${ }^{3}$ Both have been rejected by the Singapore Court of Appeal $^{4}$ and embraced by the Court of Appeal of England and Wales. ${ }^{5}$ While Lord Hoffmann's reformulated remoteness principle is now understood to represent the law in England, his analysis of implication has recently been held by a majority of the United Kingdom Supreme Court not to provide authoritative guidance on the law of implied terms. ${ }^{6}$ It will be argued that it is in fact Lord Hoffmann's reorientation of the implication of terms that stands up to close scrutiny and represents a positive development, while the same cannot be said of his reformulation of remoteness. The implication of terms in fact can properly, and helpfully, be regarded as an interpretative exercise, but the application of the remoteness doctrine cannot.

1 Attorney General of Belize v Belize Telecom Ltd [2009] UKPC 10, [2009] 1 WLR 1988.

2 Transfield Shipping Inc v Mercator Shipping Inc [2008] UKHL 48, [2009] 1 AC 61 [The Achilleas].

3 On implication compare for example David McLauchlan "Construction and Implication: In Defence of Belize Telecom" [2014] LMCLQ 203; Richard Hooley "Implied Terms after Belize Telecom" (2014) 73 CLJ 315 (in favour); Paul S Davies "Recent Developments in the Law of Implied Terms" [2010] LMCLQ 140; Wayne Courtney and JW Carter "Implied Terms: What Is the Role of Construction?" (2014) 31 JCL 151; and JW Carter and Wayne Courtney "Belize Telecom: A Reply to Professor McLauchlan" [2015] LMCLQ 245 (against). On remoteness see David McLauchlan "Remoteness Reinvented?" (2009) 9 OUCLJ 109; Paul CK Wee "Contractual interpretation and remoteness" [2010] LMCLQ 150; Mark Stiggelbout "Contractual remoteness, 'scope of duty' and intention" [2012] LMCLQ 97; and Andrew Burrows "Lord Hoffmann and Remoteness in Contract" in Paul S Davies and Justine Pila (eds) The Jurisprudence of Lord Hoffmann (Hart Publishing, Oxford, 2015) 251.

4 On implication see Foo Jong Peng v Phua Kiah Mai [2012] SGCA 55, [2012] 4 SLR 1267; and Sembcorp Marine Ltd v PPL Holdings Pte Ltd [2013] SGCA 43, [2013] 4 SLR 193. On remoteness see MFM Restaurants Pte Ltd v Fish \& Co Restaurants [2010] SGCA 36, [2011] 1 SLR 150.

5 On implication see for example Marks and Spencer plc v BNP Paribas Securities Services Trust Co (Jersey) Ltd [2014] EWCA Civ 603, [2014] 2 P\&CR DG 16 [BNP Paribas (CA)] at [21] and [24] (disapproved on appeal, see below n 6); and NRAM plc v McAdam [2015] EWCA Civ 751, [2015] ECC 30 at [48]. On remoteness see Siemens Building Technologies Ltd v Supershield Ltd [2010] EWCA Civ 7, [2010] 2 All ER (Comm) 1185; and John Grimes Partnership Ltd v Gubbins [2013] EWCA Civ 37.

6 Marks and Spencer plc v BNP Paribas Securities Services Trust Co (Jersey) Ltd [2015] UKSC 72, [2015] 3 WLR 1843 [BNP Paribas (SC)] at [24] per Lord Neuberger with whom Lord Sumption, Lord Hodge and Lord Clarke agreed. 


\section{THE IMPLICATION OF TERMS ${ }^{7}$}

\section{A From Gap-filling Rules to Ascertaining Meaning}

A number of attempts have been made over the years to encapsulate the basis on which terms are implied in fact. One of the best-known statements in the law of contract is Lord Justice Bowen's identification of the law's object in the implication of terms, which "is to give such business efficacy to the transaction" as the parties must have intended. ${ }^{8}$ And one of the law's most memorable figures is Lord Justice MacKinnon's officious bystander, who would have been testily suppressed by the parties if he had bothered them at the time of contracting about "something so obvious that it goes without saying". 9 Both the notion of something necessary for business efficacy and something so obvious that it goes without saying were included in the well-known list identified by Lord Simon in BP Refinery (Westernport) Pty Ltd $v$ Shire of Hastings of five conditions that must be satisfied for a term to be implied, along with requirements that the term must be reasonable and equitable, capable of clear expression and must not contradict any of the express terms. ${ }^{10}$

In Attorney General of Belize v Belize Telecom Ltd the Privy Council held that the implication of terms is no more or less than an exercise in determining what a reasonable addressee would understand the contract to mean. Giving the judgment of the Board, Lord Hoffmann held that the various tests for the implication of terms are simply reformulations of this question and must not be "treated as different or additional tests" or "as if they had a life of their own". ${ }^{11}$ The Privy Council declared that, in the implication of terms, "[t]here is only one question: is that what the instrument, read as a whole against the relevant background, would reasonably be understood to mean?"12

The gist of the Belize Telecom approach has been accepted by the New Zealand courts, though notably Lord Hoffmann's idea that "there is only one question" has not been embraced at the appellate level. ${ }^{13}$ It has been noted that the elements of the BP Refinery formulation remain useful

7 This section draws on Andrew Robertson "The Foundations of Implied Terms: Logic, Efficacy and Purpose" in Simone Degeling, James Edelman and James Goudkamp (eds) Contracts in Commercial Law (Thomson/LawBook Co, Sydney, 2016) (forthcoming).

8 The Moorcock (1889) 14 PD 64 (CA) at 68.

9 Shirlaw v Southern Foundries (1926) Ltd [1939] 2 KB 206 (CA) at 227.

10 BP Refinery (Westernport) Pty Ltd v Shire of Hastings (1977) 180 CLR 266 (PC) at 283.

11 Belize Telecom, above n 1, at [21]-[22].

12 At [21].

13 Most notably in Dysart Timbers Ltd v Nielsen [2009] NZSC 43, [2009] 3 NZLR 160; and Hickman v Turn and Wave Ltd [2011] NZCA 100, [2011] 3 NZLR 318. On the status of the Belize Telecom approach in New Zealand, compare Matthew Barber "Implied Terms" [2013] NZLJ 238; David McLauchlan "Construction and Implication: in Defence of Belize Telecom" [2014] LMCLQ 203 at 237; and Simon Connell "A shift from Belize to Singapore? Interpretation and implication in Satterthwaite v Gough" [2015] NZLJ 263. 
indicators, ${ }^{14}$ and business efficacy has remained centrally important in the application of what is essentially a hybrid set of principles. ${ }^{15}$ The Court of Appeal of England and Wales went further, taking the view that Belize Telecom had introduced a new approach to the implication of terms, and even a new test. ${ }^{16}$ More recently, however, the Supreme Court of the United Kingdom has held that Belize Telecom did not change the law in England. ${ }^{17}$ According to Lord Neuberger (with whom Lord Sumption, Lord Hodge and Lord Clarke agreed), Lord Hoffmann's observations are open to "interpretations [that] are wrong in law" and "should henceforth be treated as a characteristically inspired discussion rather than authoritative guidance on the law of implied terms". ${ }^{18}$ A slightly modified version of the BP Refinery criteria was held to represent the law in England, with business efficacy and obviousness serving as alternatives. ${ }^{19}$ Lord Carnwath alone argued for the continuing authority of the judgment in Belize Telecom, which he regarded as "a valuable and illuminating synthesis of the factors which should guide the court". ${ }^{20}$

\section{$B$ Meaning and Construction}

While Lord Simon's judgment in BP Refinery seemed to offer a set of rules for filling gaps in incomplete contracts, Lord Hoffmann in Belize Telecom sought to reorient the implication of terms and recast it as an interpretative exercise. Whether the implication of terms properly can be understood as an interpretative exercise is the question that will now be addressed.

To the extent that it seeks to ascertain the meaning of a contractual instrument, the implication of terms is concerned with the determination of the applicative meaning of the instrument: it seeks to solve a puzzle about the application of the instrument to a particular case. ${ }^{21}$ This is properly understood as an exercise in construction in the sense identified by Francis Leiber in his 1839 book on legal hermeneutics. ${ }^{22}$ The implication of terms deals with issues not directly addressed by a text by drawing conclusions that are based on elements within the text. Those conclusions can therefore

14 Hickman v Turn and Wave Ltd, above n 13, at [248].

15 Gibbston Downs Wines Ltd v Perpetual Trustees Ltd [2013] NZCA 506, [2014] NZCCLR 6.

16 For example BNP Paribas (CA), above n 5, at [21] and [24]; and NRAM plc v McAdam [2015] EWCA Civ 751 at [48].

17 BNP Paribas (SC), above n 6, at [24].

18 At [31].

19 At [21].

20 At [74].

21 This is one of the three different kinds of relationship between meaning and interpretation identified by Richard H Fallon "The Meaning of Legal 'Meaning' and Its Implications for Theories of Legal Interpretation" (2015) 82 U Chi L Rev 1235 at 1238.

22 Francis Lieber Legal and Political Hermeneutics (Little and Brown, Boston, 1839) at 56. 
be said to be within the spirit of the text, rather than the letter. ${ }^{23}$ The crucially important context for implication in most cases does not consist of circumstances extrinsic to the instrument, but of inferences about the nature and purposes of the instrument and particular provisions within it.

The Belize Telecom case has sometimes been said to introduce a new "test" for the implication of terms. In $X v Y$, for example, Toogood $\mathrm{J}$ held that: ${ }^{24}$

A term is implied where such a term would spell out in express words what the contract, read against the relevant background, would reasonably be understood to mean. That is the test.

That test is not easy to apply directly to particular facts, for the following reason. The implication of terms is a problem-solving exercise. The question is whether the instrument, broadly construed in its commercial context, both identifies a solution to the problem that has arisen and indicates that the solution is to govern the problem. In most implied terms cases the difficulty lies not in identifying a solution but in determining whether the obvious solution is to be applied to resolve the problem, or whether, alternatively, the risk lies where it falls according to the express terms. Asking whether the claimed implied term spells out what the contract would reasonably be understood to mean does not in itself tell us whether the obvious solution is to be applied. A further reasoning process is needed.

This point is illustrated by reference to the facts of the two most important recent cases on implied terms: Belize Telecom and Marks and Spencer $v$ BNP Paribas. In Belize Telecom the essential facts were that the articles of association of a partially privatised telecommunications company were structured so as to facilitate a sharing of control between the Government and private investors, with power given to different classes of shareholders to elect and remove directors. The articles provided that if a person held two different kinds of share then that person would have the power to appoint two directors. The articles said nothing about what was to happen if a person exercised that power and then ceased to hold one of the two qualifying classes of share. When this occurred, the two directors in question were, on the face of the articles, irremovable. There was an obvious solution to the problem: the articles clearly should have provided that any directors appointed by the special shareholder should be removed automatically upon its ceasing to hold the qualifying shareholding. Automatic removal was the obvious solution, but did the articles mean that there was to be automatic removal, or did they simply leave a gap? How can we tell?

The situation in Belize Telecom can be contrasted with the facts of Marks and Spencer $v$ BNP Paribas in order to illustrate the point. The latter case concerned a lease under which rent was

23 At 56.

$24 X v Y$ [2015] NZHC 2594 at [31] (citations omitted), citing Belize Telecom, above $\mathrm{n}$ 1, at [21] and Nielsen $v$ Dysart Timbers Ltd [2009] NZSC 43, [2009] 3 NZLR 160 at [25]. See also BNP Paribas (CA), above n 5, at [11] and [21]-[24] (implicitly disapproved by the Supreme Court on appeal BNP Paribas (SC), above n 6 , at [22]-[31]). 
payable quarterly in advance. A break clause gave the tenant an entitlement to terminate the lease on payment of a substantial break premium, but provided for the lease to come to an end part way through a rent period. The advance rent representing the period following the break date became a windfall for the landlord unless it was repayable. Because the landlord already had the benefit of the break premium, it was clear that the lease should have provided that the landlord was obliged to repay the portion of advance rent representing the period following the break date. That was the obvious solution to the windfall problem. But did the lease mean that the landlord was under such an obligation? How do we go about answering that question?

In each of these two cases it is easy to identify the obvious solution to the problem that arose, but much more difficult to say whether the contract means that the obvious solution is to govern the problem. A process of reasoning is needed in implied terms cases to determine whether the instrument, properly construed, both identifies a solution to the problem that has arisen and indicates that the solution is to govern the problem. The crucial question is how we determine whether the contract means that the obvious but unarticulated solution governs the problem.

\section{Identifying the Paths of Reasoning}

Lord Hoffmann posed the meaning question in two different ways in Belize Telecom: first as a question of what the contract means and secondly as a question of what the contract must mean. ${ }^{25}$ The latter formulation is more helpful because it leads us to consider the basis of the imperative, and therefore to identify the process of reasoning involved in determining what the contract must mean. The cases show that there are three different bases on which we might conclude that the instrument must mean that the obvious solution governs the problem: first, that may be what the instrument must mean as a matter of language and logic; secondly, it may be what the instrument must mean in order to make the transaction workable; and thirdly, it may be what the instrument must mean in order to avoid defeating a subsidiary purpose underlying the instrument or a particular provision of the instrument.

\section{Necessitated by language and logic}

Implied terms within the first category undoubtedly represent the meaning of the instrument. They are implications arising as a matter of logic or necessary inference from the language of the express terms of the contract. The clearest example of an implied term within this category is a negative covenant which is the corollary of an express promise. A promise to take all requirements of electricity from a particular supplier implies a promise not to take electricity from any other supplier. ${ }^{26}$ Other cases are less clear. An example of a case at the outer edge of this category is Hart

25 Belize Telecom, above n 1, at [16], [18] and [19]. See also at [21] ("would reasonably be understood to mean"), and [22] and [27] ("actually means").

26 Metropolitan Electric Supply Co Ltd v Ginder [1901] 2 Ch 799. 
$v$ MacDonald, where a promise to pay a purchase price for machinery out of the proceeds of a dairy was held to imply a promise to operate the dairy. ${ }^{27}$ The obligation to operate the dairy was a logical implication from the fact that the price was to be paid, but only from the proceeds of the dairy. Implications of this kind are sometimes referred to as a "constructional implication", ${ }^{28}$ but this may be considered an unhelpful label if it is accepted, as argued here, that all terms implied in fact are identified through a process of construction. Whatever the label, it cannot be disputed that terms implied within this category do no more than spell out what a reasonable person would understand the instrument to mean.

\section{Necessary to give business efficacy to the contract}

The second basis for implication is that a problem has arisen in the application of the contract which must be resolved in order to give the contract business efficacy or make it work, and there is an obvious solution to the problem. The element of business efficacy goes primarily to the quality of the problem and establishes that the problem is one that must be solved. It goes hand in hand with the requirement of obviousness: the problem can only be solved if there is an obvious solution which must be understood to have been implicitly adopted. The element of obviousness goes to the quality of the solution and establishes that this particular solution must be applied to resolve the problem. It is the need to make the contract workable that supplies the imperative and justifies the conclusion that the obvious solution must be implied in order to save the contract. ${ }^{29}$

\section{Necessary to avoid defeating a contractual purpose}

The third basis on which it can be concluded that a contract must be understood to include an implied term is that the term is necessary to avoid defeating a contractual purpose. Necessity to avoid defeating a contractual purpose has clearly operated as a basis for deciding some important cases, but has not yet been acknowledged as a basis for implication. Where a contractual purpose goes to the heart of the bargain and an implication is needed to prevent that core contractual purpose from being defeated (either by circumstances or by the actions of one of the parties) then an implication can be justified under the business efficacy principle. But contracts also have subsidiary purposes, which do not go to the heart of the bargain, and implications are sometimes necessary to protect those subsidiary purposes. Like business efficacy, necessity to avoid defeating a contractual purpose is coupled with obviousness as a basis for implication. Necessity to avoid defeating a

27 Hart v MacDonald (1910) 10 CLR 417 (HCA).

28 See for example Mosvolds Rederi A/S v Food Corp of India [1986] 2 Lloyd's Rep 68 (QB (Comm)) at 70.

29 This is broadly consistent with the notion that business efficacy and obviousness are cumulative and complementary requirements, which was developed by Andrew Phang "Implied Terms Revisited" [1990] JBL 394 at 396; and Andrew Phang "The Challenge of Principled Gap-Filling: A Study of Implied Terms in a Comparative Context" [2014] JBL 263 at 287-295. The notion was adopted in Forefront Medical Technology (Pte) Ltd v Modern-Pak Pte Ltd [2006] SGHC 3, [2006] 1 SLR (R) 927 at [33]-[40]; and Sembcorp Marine Ltd v PPL Holdings Pte Ltd, above n 4, at [90]. 
contractual purpose goes to the quality of the problem - establishing that the problem is one that must be solved - while the element of obviousness goes to the suitability of the solution establishing that the particular solution must be what solves the problem.

It was the combination of necessity to avoid defeating a contractual purpose and the presence of an obvious solution that justified the conclusion in Belize Telecom that the articles of association must be understood to include the implied term. Lord Hoffmann said that: ${ }^{30}$

... the implication is required to avoid defeating what appears to have been the overriding purpose of the machinery of appointment and removal of directors, namely to ensure that the board reflects the appropriate shareholder interests in accordance with the scheme laid out in the articles.

The reasoning in Belize Telecom therefore supports the notion that a reasonable addressee will be compelled to conclude that a term is implied if such a term is necessary to give effect to a contractual purpose.

A second example is Equitable Life Assurance Society $v$ Hyman. ${ }^{31}$ In that case the society issued two different types of life assurance policy which drew on a single investment pool. One type provided an annuity rate guarantee and one did not. When the market rate for annuities fell below the guaranteed rate, the directors began adjusting the final bonus for those policyholders who had the benefit of an annuity rate guarantee and chose to take the guaranteed rate. The directors adopted that practice in order to ensure that investment returns were distributed equally between those with the annuity rate guarantee and those without. This effectively neutralised the annuity rate guarantee. The guarantee was honoured, but was deprived of effect through adjustment of the bonus, which, according to the articles, was within the discretion of the directors. The House of Lords held that an implied term prevented the Society from declaring a differential final bonus and thereby depriving the annuity rate guarantee of substantial effect. The implication was not necessary to make the contract work. As Hugh Collins has pointed out, the contract could function perfectly well as an investment vehicle and pensions device without the implied term. ${ }^{32}$ But the implication was necessary to avoid defeating the commercial object of the annuity rate guarantee, which Lord Steyn said was "to protect the policyholder against a fall in market annuity rates". ${ }^{33}$ The implication was needed, in other words, to protect a subsidiary contractual purpose.

30 Belize Telecom, above $\mathrm{n}$ 1, at [32].

31 Equitable Life Assurance Society v Hyman [2002] 1 AC 408 (HL).

32 Hugh Collins "Implied Terms: The Foundation in Good Faith and Fair Dealing" (2014) 67 CLP 297 at 317.

33 Equitable Life Assurance Society v Hyman, above n 31, at 459. 


\section{Obviousness and Singularity}

\section{An obvious solution}

It has been argued up to this point that the reader of a contractual instrument is compelled to conclude that the instrument must by implication include a particular provision if there is: first, a gap that must be filled; and secondly, an obvious means of filling it. I want to suggest, however, that what is needed is not necessarily an obvious solution to the problem in question, but one that is singularly apt. It is well accepted that, even if something is needed to make a contract work, a term will not be implied if there are several equally reasonable ways of solving the problem. ${ }^{34}$ This fits with the interpretative view of implied terms: if multiple equally compelling solutions are available then it cannot be said that the contract must mean that any one of them was adopted, and a reasonable addressee would not conclude that any term is implied. The unworkable contract cannot then be saved.

It is not necessary, however, that the solution be an obvious one, but only that it be singularly appropriate. As Lord Justice Bingham has said, it must "be shown either that there was only one contractual solution or that one of several possible solutions would without doubt have been preferred". ${ }^{35}$ The distinction between an obvious solution and one that is singularly apt may not be significant in most cases because the solution will be obvious as well as singular. But as Lord Hoffmann pointed out in Belize Telecom, an implied term should not be barred on the basis that the answer to the problem is not immediately apparent and some careful consideration is needed, provided one would conclude that there is only one answer that is consistent with the instrument. Where the implied term expresses a singularly appropriate solution to a problem that must be solved, then a reasonable addressee would conclude that the instrument must mean that the solution is to be applied to resolve the problem.

\section{Obviously intended}

The discussion of "obviousness" thus far has referred to an obvious solution to the problem created by a contractual gap. In this area of the law, however, obviousness is usually used to refer to something that was obviously intended by the contracting parties. It is well accepted that logic and business efficacy alone are too constraining and do not exhaust the categories of terms implied in fact. The United Kingdom Supreme Court held in Marks and Spencer v BNP Paribas that, although the elements set out by Lord Simon are otherwise cumulative, "necessity and obviousness ... can be

34 Trollope \& Colls Ltd v North West Metropolitan Regional Hospital Board [1973] 1 WLR 601 (HL) at 609610 per Lord Pearson, with whom Lord Guest and Lord Diplock agreed, and 614 per Lord Cross; and Codelfa Construction Pty Ltd v State Rail Authority of NSW (1982) 149 CLR 337 (HCA) at 355-356 per Mason J, with whom Stephen and Wilson JJ agreed.

35 Philips Electronique Grand Public SA v British Sky Broadcasting Ltd [1995] EMLR 472 (CA) at 482 per Sir Thomas Bingham MR. 
alternatives in the sense that only one of them needs to be satisfied". ${ }^{36}$ Whether something is so obvious that it goes without saying is usually tested through the application of the officious bystander test. The officious bystander test has been strongly criticised by scholars and judges on a number of different bases, most recently by Lord Hoffmann in Belize Telecom. ${ }^{37}$ As a legal standard or test, the idea of something being so obvious that it goes without saying is very weak. It does not prescribe a reasoning process and therefore functions as a statement of conclusion rather than a tool of analysis.

Neither the obviousness standard nor the officious bystander test therefore provides a solid foundation for a conclusion that a contract must mean that a particular term was implied. But if necessity to avoid frustrating a contractual purpose is accepted as a basis for implication then obviousness is not needed as an alternative foundation. Many of the leading English cases that are commonly cited in support of the view that obviousness provides an alternative to business efficacy provide that support only by way of obiter dicta. The few cases which were decided on that footing are better explained on the basis that the term was necessary to avoid defeating a subsidiary contractual purpose. ${ }^{38}$

\section{E Meaning and Implication}

The implication of terms in fact can properly be understood as a gap-filling doctrine in the sense that, where the doctrine can be applied, it has the effect of filling gaps in the express terms. But since it fills those gaps through a process of construction, drawing on the sprit rather than the letter of contractual instruments, it can be concluded that in cases in which terms are implied in fact there is no gap in the meaning of the instrument. The implication of terms in fact is concerned to identify what a contractual instrument must mean as a matter of logic, in order to make the contract work or in order to avoid defeating a subsidiary contractual purpose. In the latter two cases the implication is compelled by the combination of necessity and the existence of a singularly apt solution to the problem at hand.

\section{THE REMOTENESS RULE}

The remoteness rule has a much narrower scope of application than the implication of terms. It also has a fundamentally different orientation, being concerned with breach rather than performance. The implication of terms is concerned primarily with the parties' rights and obligations in relation to performance and the limits of their contractual powers and discretions. The remoteness rule, in contrast, simply determines the limits of a contract breaker's liability for damages. In dealing with remoteness issues, therefore, we are not only in the realm of breach, rather than performance,

36 BNP Paribas (SC), above n 6, at [21].

37 Belize Telecom, above n 1, at [25].

38 See Robertson, above $\mathrm{n} 7$. 
but are concerned only with the law's response to breach, which is to order the payment of compensatory damages.

While contracting parties can exclude or limit the obligation to pay damages for breach and can stipulate for payment of liquidated damages, they commonly do not do so. The obligation to pay compensatory damages for breach is therefore a prime example of a default rule: it is a rule supplied by the law, which the parties can modify by agreement if they choose to do so. ${ }^{39}$ The basic principle that a party in breach of contract can be required to pay compensatory damages forms part of a broader set of default rules. The basic principle is supplemented by a set of rules that specify the way in which the defendant's liability to compensate the plaintiff will be determined and quantified, including rules on causation, remoteness, mitigation and the types of loss that are compensable. In some instances modification of the law's default rules on damages for breach constitutes an important part of the bargain, but in most cases there is no express modification of those rules. In cases where contract terms deal expressly with the payment of damages, then the extent of a contract breaker's liability for damages will clearly depend on an interpretation of the parties' agreement. But the present question is whether, in the absence of express provisions concerning damages for breach, the application of the default common law remoteness rule can be understood as an exercise in interpretation of the agreement.

\section{A The Basic Rule}

The essence of the remoteness rule is that a contract breaker is only liable for loss of a kind that was within the scope of reasonable contemplation at the time the contract was made. More fully, whether a defendant is liable for a particular type of loss depends on a question formulated along the following lines. If a reasonable person in the position of the defendant had, at the time the contract was made, considered the possibility of a breach, would loss of the relevant kind have been within that person's contemplation as a serious possibility or not unlikely consequence of the breach $?^{40}$ That question unifies the two limbs identified by Alderson B in Hadley $v$ Baxendale: namely, loss arising "according to the usual course of things" and loss resulting from special circumstances known to the defendant. ${ }^{41}$ Expressed in terms of foreseeability, it may be said that a contract breaker is liable only for loss that could be foreseen as not unlikely to occur. ${ }^{42}$

That core remoteness rule is understood by some to be founded on the agreement of the parties. In The Achilleas, a majority of the House of Lords considered that the rule simply identifies the

39 See Ian Ayres and Robert Gertner "Filling Gaps in Incomplete Contracts: An Economic Theory of Default Rules" (1989) 99 Yale LJ 87.

40 Koufos v C Czarnikow Ltd [1969] 1 AC 350 (HL) [The Heron II] at 385 per Lord Reid.

41 Hadley v Baxendale (1854) 9 Exch 341 at 355.

42 The Heron II, above n 40, at 389 per Lord Reid, using the word "likely", though "not unlikely" better reflects the views expressed in the other speeches. 
risks for which the defendant can be said to have assumed responsibility. ${ }^{43}$ The basis of the remoteness rule, according to Lord Hoffmann, is that contractual liability is voluntary and therefore extends only to risks voluntarily undertaken by the defendant: "It seems to me logical to found liability for damages upon the intention of the parties (objectively ascertained) because all contractual liability is voluntarily undertaken." 44

The interpretative basis of the core remoteness rule is put even more strongly by the editors of Chitty on Contracts, who suggest that: ${ }^{45}$

... it can be said in general terms that the promisor implicitly accepts responsibility for the usual consequences of a breach of the promise in question, while the promisee implicitly accepts the risk of any other consequences. (In other words, the promisee implicitly agrees not to hold the promisor responsible for unusual consequences.) The test seems ultimately to depend on the express or implied intention of the parties.

It is difficult to see this as anything other than a fiction. The idea is that the mere entry into a contract which creates performance obligations involves the acceptance of responsibility for the usual consequences of a breach of those obligations. Moreover, and even less credibly, the promisee's entry into the contract is itself said to imply a promise not to hold the promisor responsible for consequences lying outside the rule in Hadley $v$ Baxendale. The entry into the contract is the only manifestation of assent to this allocation of risk.

A significant barrier to understanding the remoteness rule in this way is the idea that contracting parties generally contract for performance rather than breach. Widespread assertions along these lines by judges and scholars are supported by the terms of most contracts, which typically say nothing about the consequences of breach. ${ }^{46}$ They are also supported by empirical studies showing that people are, in general, unrealistically optimistic and tend to underestimate the likelihood of adverse events. ${ }^{47}$

This insight is important not because we are concerned about the subjective intentions of contracting parties, but because it tells us how we should interpret the behaviour and communications of contracting parties from an objective standpoint. It tells us what contracting parties can be taken to be communicating about, which is performance, rather than breach. Lord

43 The Achilleas, above n 2, at [12]-[22] per Lord Hoffmann, [31]-[33] per Lord Hope and [69] per Lord Walker.

44 At [12].

45 HG Beale (ed) Chitty on Contracts (32nd ed, London, Sweet \& Maxwell, 2015) at [26-107] (citations omitted).

46 See Andrew Robertson "The Basis of the Remoteness Rule in Contract" (2008) 28 LS 172 at 176.

47 At 176 
Hoffmann has pointed out extrajudicially that the test for remoteness is objective, so it does not matter what the parties did or did not consider or intend at the time of contracting. ${ }^{48}$ But if contracting parties stipulate only performance terms and there is no indication that they adverted to the possibility of breach, let alone its consequences, then there is unlikely to be any objective manifestation of an intention to allocate the risk of particular consequences of breach. The entry into a contract that includes only performance terms does not communicate anything about liability for the consequences of breach.

If the remoteness rule cannot be understood as a means of interpreting the agreement or identifying an allocation of risk made by the contracting parties, then we must accept that it is an externally imposed rule based on fairness. It is a default rule which effects a fair allocation of a risk which the parties themselves have failed to allocate ${ }^{49}$ It is fair to hold a contract breaker liable only for loss of a kind that a reasonable person would have contemplated if he or she turned his or her mind to the possibility of the relevant type of breach at the time the contract was made. This gives a contracting party an opportunity to consider the risks that might arise from breach and, where necessary, take action either to avoid them or factor them into the contract price. More extensive liability could deprive the contract breaker of a reasonable opportunity to behave differently in the face of that risk.

The choice between these two alternative explanations for the remoteness rule is not simply an academic question. The basis of the rule is of great importance because it determines the scope of application of the rule and the circumstances in which it is appropriate or necessary to depart from it.

\section{B Departures from the Basic Rule}

It is now well accepted that the core remoteness rule may work injustice in some instances. First, the rule may in some situations be under-inclusive. There may be circumstances in which a particular type of loss is insufficiently likely to satisfy the basic rule, but the party in breach should nevertheless be held liable for that loss. The under-inclusiveness of the rule may be thought to be illustrated by Supershield Ltd v Siemens Building Technologies FE Ltd. ${ }^{50}$ In that case the negligent installation of a float valve on a water tank caused damage by flooding, but only because a back-up bunding and drainage system also happened to fail. The presence of the bund wall and drains meant that flooding was an unlikely outcome of the failure of the valve, but the Court of Appeal of England and Wales nevertheless held that the loss was not too remote. The case does not seem to evidence the under-inclusiveness of the basic remoteness rule, however, but only to tell us that some

48 Lord Hoffmann "The Achilleas: Custom and Practice or Foreseeability?" (2010) 14 Edin LR 47 at 60.

49 Robertson, above n 46, at 180-181.

50 Supershield Ltd v Siemens Building Technologies FE Ltd, above n 5. 
flexibility is needed in relation to the degree of probability, especially in cases where the only real risk arising from a breach is one that is quite unlikely to eventuate. Alternatively, as Andrew Burrows has argued, it might be thought necessary to take account of the purpose of the duty that has been broken. ${ }^{51}$ The risk that eventuated was the very risk that the customer sought to guard against through the installation of the float valve.

A slightly more significant problem is that it may not always be just to impose liability for loss that is within the reasonable contemplation of the parties. The well-worn hypothetical illustration is a taxi driver who accepts a fare knowing that his passenger is on her way to an important business meeting and stands to lose the benefit of a substantial business deal if she is late. If the driver's breach of contract causes the passenger to miss the meeting, the passenger's consequential loss falls within the rule. It may be doubted whether the driver should be held liable for that loss, but different reasons have been advanced to explain why that is the case, and different principles advanced to explain the basis on which, and therefore the circumstances in which, the courts should depart from the basic remoteness principle.

If the basis of the remoteness rule is that the law provides for a fair allocation of a risk that was not allocated by the parties, then a departure is justified where the core rule does not produce a fair allocation. The second Restatement of Contracts suggests that in the United States foreseeable loss will not always be recoverable, and the court may limit a damages award in order to avoid disproportion between defendant's liability and the benefit he or she stood to receive from the contract. ${ }^{52} \mathrm{~A}$ simple rule of that kind is sufficient to deal with the taxi driver example, but more sophisticated riders or qualifications to the basic remoteness rule have been proposed, encompassing a wide range of matters such as whether the defendant had an opportunity to limit his or her liability, the nature and extent of the defendant's culpability and insurance practices in the relevant industry. ${ }^{53}$

In The Achilleas some members of the House of Lords preferred an interpretative explanation for departures from the remoteness rule in situations like the taxi driver example and, accordingly, an interpretative approach to determining when there should be a departure from the basic rule. The Achilleas concerned the late redelivery of a ship by a charterer. On its last voyage, the ship was delayed in port and the charterers returned the ship nine days late. That late redelivery caused the owner to miss the last delivery date for the follow-on charter. This in turn gave the follow-on charterer the right to cancel, which they were no doubt pleased to be able to do because market rates had been very high when the follow-on charter had been fixed, and had since fallen sharply. The

51 Burrows, above $\mathrm{n} 3$, at 263.

52 American Law Institute Restatement of Contracts (2nd ed, St Paul, Minnesota, 1981) § 351(3).

53 See Robertson, above n 46, drawing on, inter alia, Robin Cooke "Remoteness of Damages and Judicial Discretion" (1978) 37 CLJ 288. See also McLauchlan "Remoteness Reinvented", above n 3, at 129-133. 
owner therefore had to accept a much lower rate from the follow-on charterer, resulting in a loss of approximately USD 1,300,000.

The Achilleas raised the question whether a charterer breaching a contract through late redelivery was liable for loss of profit on a subsequent charter. There was an understanding in the shipping industry that a charterer's liability for late redelivery was limited to the difference between the market rate and the charter rate for the period of the overrun, and this understanding was supported by obiter dicta in some cases and statements in textbooks. On that basis, the charterer's liability would have been about USD 160,000. The majority arbitrators nevertheless held that the loss fell within the first limb of Hadley $v$ Baxendale and was therefore not too remote. It was within the scope of reasonable contemplation at the time the contract was made that a follow-on charter was likely to have been fixed and would be placed in jeopardy by late redelivery. Christopher Clarke $\mathbf{J}$ agreed, as did a unanimous Court of Appeal.

The House of Lords held unanimously that the loss was too remote. Lord Hoffmann and Lord Hope held in effect that there was an exception to the general remoteness rule in the case of loss of a type or kind for which the defendant has not assumed responsibility. ${ }^{54}$ Lord Rodger and Baroness Hale held that the loss was too remote under the basic remoteness rule: the loss was a result of the extreme volatility in the market, which could not have been reasonably foreseen as likely to arise out of the delay. ${ }^{55}$ Lord Walker gave similar reasons but also agreed with Lord Hoffmann, Lord Hope and Lord Roger, ${ }^{56}$ leaving scope for argument as to the effect of the decision on the status of the remoteness rule.

If the crucial issue is whether the defendant has assumed responsibility for the type of loss in question, how are courts and legal advisers to determine whether the defendant has done so? In The Achilleas both Lord Hoffmann and Lord Hope based the conclusion that the charterer had not assumed responsibility for the loss of the follow-on charter squarely on the fact that the loss could not be controlled or quantified by the charterer ${ }^{57}$ But as David McLauchlan and Andrew Burrows have pointed out, it is not uncommon for a contract breaker to be held liable for loss that he or she cannot quantify, predict or control. ${ }^{58}$ The Heron II is one prominent example of this. ${ }^{59}$ Another explanation, which was subsequently given extrajudicially by Lord Hoffmann, is that the industry understanding justified the conclusion that the defendant had not assumed responsibility for the

54 The Achilleas, above n 2, at [12]-[26] per Lord Hoffmann and [32] per Lord Hope.

55 At [60] per Lord Rodger and [91]-[93] per Baroness Hale.

56 At [87].

57 At [23] per Lord Hoffmann and [36] per Lord Hope.

58 Burrows, above n 3, at 257; and McLauchlan "Remoteness Reinvented?", above n 3, at 124.

59 The Heron II, above n 40. 
risk. ${ }^{60}$ But even assuming that we can attribute the industry understanding to the defendants, it reflected what they might be taken to have thought the law was, not the liability they were assuming.

The Achilleas is now understood to have changed English law on remoteness, leaving the basic rule in place, but allowing for departure where loss is either within reasonable contemplation but the defendant cannot be understood to have assumed responsibility for it, or loss is outside reasonable contemplation but the defendant has assumed responsibility for it. ${ }^{61}$ The problem with this development is that it is founded on the idea that the core remoteness rule generally identifies types of loss for which the defendant has assumed responsibility. If the core remoteness rule (of liability for loss that is within the scope of reasonable contemplation) cannot convincingly be understood to identify such types of loss, then it is entirely unclear when the general rule should be applied and when departure is justified. In providing a qualification of uncertain scope to the core remoteness rule, The Achilleas renders uncertain the scope of application of the core rule. In the absence of a discernable manifestation of intention, there is no reliable or clear basis for saying that the defendant has or has not assumed responsibility for any particular kind of loss. There is therefore no reliable way of knowing when the core rule should be applied. Moreover, unlike the implication of terms, it is not possible to identify any general paths of reasoning leading to the conclusion that a contractual instrument must be understood to mean that a risk has or has not been assumed by a defendant. ${ }^{62}$

Uncomfortable as it may be to acknowledge that the remoteness rule is based on fairness, rather than interpretation, it is necessary to do so in order to develop an understanding of the factors to be taken into account in determining whether and when there should be departures from the core rule of liability for types of loss that are within the scope of reasonable contemplation. To take just one example, it is unclear whether the defendant's culpability is a relevant question. A particular issue is whether a defendant who has deliberately broken a contract should be liable for loss that is outside the scope of reasonable contemplation. While some have argued that the defendant's culpability is a relevant question, ${ }^{63}$ Andrew Burrows has suggested that this "seems alien to the English approach in contract law". ${ }^{64}$ If it were openly acknowledged that the remoteness rule is based on fairness and

60 As Andrew Burrows has pointed out, the existence of an industry understanding as to the limits of a carrier's liability based on a longstanding Court of Appeal decision (The Parana (1877) 2 PD 118 (CA)) did not stop the House of Lords in The Heron II from awarding a loss of profits against a carrier in contravention of that understanding of the law. See Burrows, above n 3, at 257-258.

61 See the cases cited above at $\mathrm{n} 5$.

62 Although it is possible to identify some kinds of conduct by which a defendant might manifest an intention to accept a particular risk, such as raising the contract price on learning of it, cases involving such manifestations of intention do not seem to come before the courts.

63 See Robertson, above n 46, at 192-193.

64 Burrows, above n 3, at 264, n 46. 
that departures from the core rule depend on fairness considerations, it is difficult to imagine that basic questions such as the relevance of the defendant's culpability could remain unresolved for long. Under an interpretative approach to remoteness, on the other hand, the relevance of the defendant's culpability, like any other factor, remains an open question in each case. ${ }^{65}$

\section{CONCLUSION}

The implication of terms may be understood as an exercise in wringing the last drops of meaning from a contractual instrument. The contractual instruments under analysis do not provide explicit answers to the issues in question. But we can identify paths of reasoning leading convincingly to the conclusion that the instruments in question must be understood to mean that the problems that have arisen are to be resolved in particular ways. It should not be surprising that the various accepted tests for implication provide some very useful guidance as to the paths of reasoning that can lead to that conclusion. The implication of terms does lie within the bounds of the interpretative enterprise, but it is not sufficient simply to ask what the instrument means. More precise guidance is needed. The case law provides guidance as to the available paths of reasoning, but viewing implication as an exercise in interpretation undoubtedly helps to illuminate those paths.

There are, however, no similar abstract paths of reasoning available in the remoteness cases. In the absence of a manifestation of intention (such as an increase in price in response to being informed of a particular risk), there are no convincing bases on which we can conclude that the parties have implicitly allocated responsibility for remote risks. It may be an uncomfortable fact that the allocation of an unallocated contractual risk is sometimes a matter for the law. But if an allocation of risk has been left to the law, then that fact must be recognised before we can begin to understand and analyse the principles that govern the basis on which the law is to make that allocation. The application of interpretative principles to a set of cases in which there is typically no relevant manifestation of intention, and no basis on which to determine what the instrument must mean, is an unsettling development and an unilluminating addition to the law.

65 See McLauchlan "Remoteness Reinvented?", above n 3, at n 146. 
